Regular Research Article

\title{
Gaps in the thread: Disease, production, and opportunity in the failing silk industry of South Sulawesi
}

\author{
Sitti Nuraeni ${ }^{1, *}$ \\ 1 Forestry Faculty, Universitas Hasanuddin, Tamalanrea, 90245, Indonesia. Email : nuraenisitti@gmail.com, \\ sitti.nureny@unhas.ac.id \\ * Corresponding author
}

\begin{abstract}
Indonesian silk farming (Sericulture) has experienced two waves of a pebrine epidemic (also known as pepper disease) and grasserie. The first pebrine epidemic occurred in 1973 and the second one occurred in 2010. Natural silk production in Indonesia has undergone dramatic decline after these epidemics. In addition to the disease, other factors also simultaneously contributed to the decline. This research examines the conditions and challenges to national natural silk industry recovery after a pebrine epidemic. The present study employs a survey and focus group discussion in three regencies (Wajo, Soppeng, and Enrekang), which took place in September 2016. Findings show that there are three major factors which contribute to the decline of national silk production, namely the: i) epidemic of silkworm disease, ii) quality of silkworms and the process of silkworm provision, iii) insufficiency of farmer means of production, and iv) lack of guidance and assistance for the farmers. Without interventions and greater support to properly maintain silkworm operations a potentially lucrative economy for rural farmers could go unrealized. The implications of this research also highlight key potential interventions for working with communities and supporting the overall resilience of national silk production in Indonesia.
\end{abstract}

Keywords: Indonesia sericulture; rural livelihoods; smallholder silk production; silk disease

\section{Introduction}

The largest threat to global sericulture is the epidemic of disease which attacks silkworm eggs and larva (Aydin et al., 2007; Govindan et al., 2007; Bhat et al., 2009; Guo-Ping and Xi-Jie, 2011; Atmosoedarjo, 2000). Serious diseases that can destroy silk cocoon harvest include pebrine and grasserie (JICA, 1985; Yup-lian, 1991; Etebari et al., 2007; Hussain and Buhroo, 2011; Nath et al., 2012). The Pebrine disease was responsible for sericulture collapse in several European countries and resulted in drastic drops in global silk production in the $19^{\text {th }}$ century (Singh et al., 2012), which originated in France and Italy and spread to Spain, Syria and Romania (Bhat et al., 2009). Pebrine disease outbreaks occurred for the first time in Indonesia in 1973 (Gitosewojo, 1995; Disperindag Sulsel, 2006) and again returned at the beginning of 2010 (BPA, 2015; Balai PSKL Wilayah Sulawesi, 2016). Silkworm diseases are the most significant factor that impacts cocoon production (Watanabe, 2002; Potrich, et al. 2007). Other than disease, national silk production in Indonesia has also decreased drastically due to other factors. This includes competition from other land based commodities that include mulberry, cacao, and other horticultural plants, the low quality of silkworms, low prices of silk products, and lack of support for silkworm production programs and organizations (Fahmid et al., 2011).

Various attempts have been made to revive the national natural silk industry. Attempts to control pebrine disease outbreaks during the first epidemic were made by replacing local silkworm lines with F1 hybrid seeds provided by government-appointed producers. They also instituted a ban on farmers breeding seeds by themselves. In addition, the government also attempted to control pebrine disease infestations at almost all sericulture production centers. In relation to production centers in South Sulawesi, government programs also sought to diversify to new http://journal.unhas.ac.id/index.php/fs/index 
development areas outside to achieve more intensive sericulture production. New development areas are mainly aimed at potential areas among locations within state forest areas. Beyond seeking new potential locations, ministries seeking to develop a footprint through the Forest Management Unit (KPH) model hope to incorporate silkworm production in new ways, and regional governments are eager to support through silkworm stock subsidies, but which would require collectively partnering to support new policies regarding silkworm rearing.

The natural silk business includes a set of activities, which begins by mulberry cultivation (moriculture) and silkworm rearing (sericulture). These stages are part of the upstream segment. The next activity is reeling raw silk from cocoons or the process of drawing fibers into threads (filature). Thereafter, the thread is delivered to the weaving industry and its derivations (manufactures) which are known as the downstream segment.

National sericulture involves several key stakeholders. These include the central and regional government, department of research and development, universities, finance organizations, entrepreneurs, non-governmental organizations and farmers. These stakeholders include: the Ministry of Forestry that support upstream sectoral development such as mulberry and silkworm production including the Natural Silk Production Agency of Bili Bili (BPA Bili Bili) that was subsumed into the Social Forestry and Environmental Partnerships Agency (BPSKL) of the Sulawesi region; the Research Agency for the Development of Environment and Forest products (BP2LHK); the Ministry of Industry working on downstream sectoral efforts to support silk yarn production at the community level; the Ministry of Cooperatives, Small, and Medium Enterprises that provide support programs; The Ministry of State Owned Enterprises (BUMN) through Perum Perhutani as a producer of silkworm eggs; The National Agricultural Quarantine Agency as a control agent for disease outbreaks from foreign and domestic egg imports and distribution; higher education institutions and NGOs involved in research and development; and, the Silk Solution Centers (SSC) in each regency that facilitate as production centers. The performance and role of each stakeholder often encounters obstacles however, which have a rippling effect for the overall industry. Each of these stakeholders however, hope that Indonesian natural silk can be more productive due to its high potential. This national superior product could be maintained to support rural economies around forests.

South Sulawesi is a national production center for silk. In other words over $80 \%$ of total national supply comes from the province. South Sulawesi also acts as a central cluster for the silk industry, throughout the upstream and downstream aspects of the sector, including mulberry planting, silkworm breeding, cocoon spinning, yarn production, and weaving at the community level. After the recent pebrine epidemic, numerous stakeholders are eager to see the recovery of South Sulawesi sericulture production, in ways that can compete with China and India's resurgence, and become a global player that can match the golden ages of the European sericulture industry. This paper presents the results of surveys and in depth discussions with various stakeholders. I explore the key periods of weaknesses associated with the pebrine epidemic in order to understand the breakdowns associated with natural sericulture cultivation, production, and management. In this way, this paper seeks to evaluate the robustness of an industry with high potential, and furthermore to identify potential areas for developing greater resilience in national sericulture.

\section{Methods}

This research was conducted through surveys and focus group discussions (FGDs). The survey and FGD were conducted while assisting a visit from entrepreneurs from Ando Co., Ltd Japan and Chul Thai Silk Co., Ltd Thailand. The data used in this research include primary and secondary data. The primary data was obtained by direct observations and interviews, while secondary data are obtained from searching and analyzing materials such as coordinating meeting agenda, proceedings, journals, books and other literatures as references. The data were analyzed descriptively and quantitatively to explore national sericulture productivity and South Sulawesi as national production center. 
The research was conducted in three major sericulture centers in South Sulawesi, which are Wajo, Soppeng and Enkerang regencies. Interviews and FGDs were conducted on a research visit conducted on September 22 until September 25, 2016. Interviewees include farmers, silk craftsmen, entrepreneurs, Perum Perhutani (seed producers), Capital Investment Coordinating Board (BKPM), Awota Forest Management Unit (KPH Awota) and regional government in each regency.

\section{Results}

\subsection{Sericulture productivity after pebrine epidemic}

Figure 1 shows that the outbreak reached its peak in 2010, however the symptoms were already beginning to show in 2007-2008, in which raw silk production drastically declined. In the following years after 2010, production continued declining and the disease was not yet under control. The data also shows that prior to the outbreak, between 2002 until 2008, raw silk production ranged from 37 to 59 tons, with the average pebrine incident percentage under $3 \%$. In 2009, pebrine infection levels were relatively low (2.93\%), but direct observations among farmers tell a different story. According to local farmers, the infection rate was remarkably higher, and $100 \%$ of farmers indicated experiencing the epidemic. Based on surveys, disease epidemics that began at the farmer level resulted in total failed harvest in 2009 and then impacted the silkworm producers in 2010 such that $56.8 \%$ production dropped to $19.2 \%$. The fluctuation of rawsilk production between 2002 to 2008 was a result of the poor quality of silkworms. This epidemic then spread evenly in rearing centers which lead to the overall crash of national silk production (from $56.8 \%$ to $19.2 \%$ ). For contrast to the historical French case, the pebrine disease epidemic in cocoon production 112qualed 26,000 tons in 1853 and fell to 4000 tons in 1865 (Singh et al., 2012).

The overall national and regional (South Sulawesi) raw silk production is shown in Figure 2. The volume of national raw silk production follows the same trend of decline by those observed in local production in South Sulawesi. As production of raw silk declines in South Sulawesi national stocks also experience decline, leading to a gap between supply and demand. Each year, the demand of raw silk ranged from 550 to 800 tons (BPA, 2013). However, only $3.8 \%$ of demand could be fulfilled after the pebrine epidemic in 2012. The gap between demand and production capability led to massive imports of authentic silk thread and other synthetic threads to meet the demand of the silk industry.

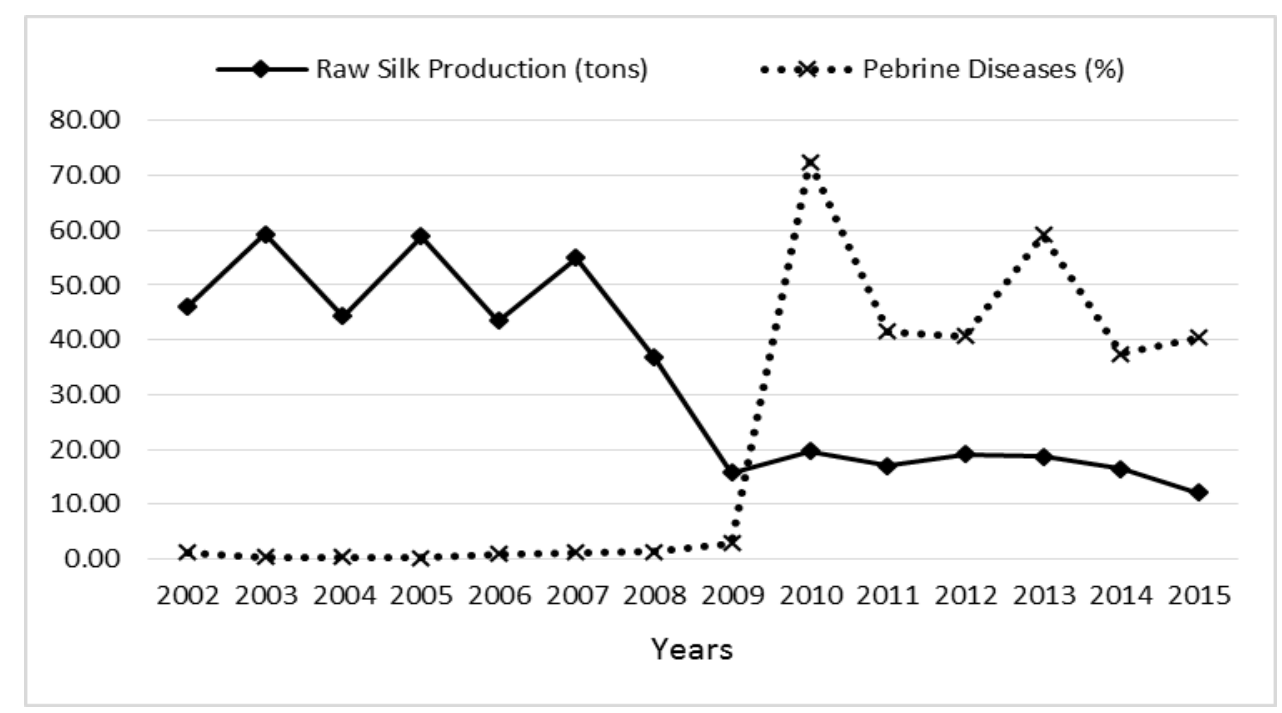

Figure 1. Production of nationwide raw silk and pebrine disease (BPA, 2015) 


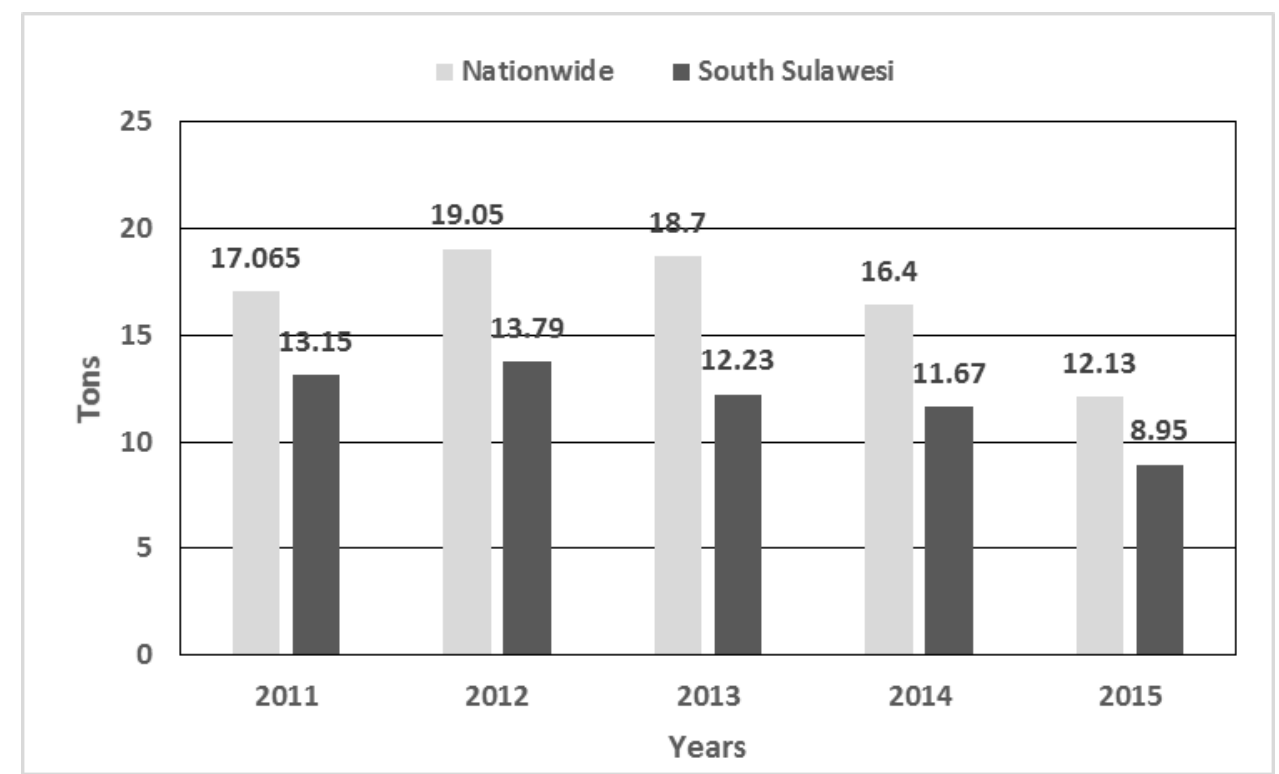

Figure 2. Production of nationwide raw silk and production of several provinces in South Sulawesi provinces (BPA, 2015)

The area of mulberry fields, number of active farmers and the absorption of silkworm eggs is shown in Figure 3. South Sulawesi has been widely known as a national silk center, and contributes $80 \%$ of total national production. However, the absorption of silkworm eggs from Perum Perhutani and aid from BPA Bili Bili continues to decline in line with the decreasing number of silkworm farmers. Low production of raw silk is influenced by a number of challenges which simultaneously affect overall production system. Other than accessing silkworms from Perum Perhutani stock is also available at the BPA but there are limited boxes available.

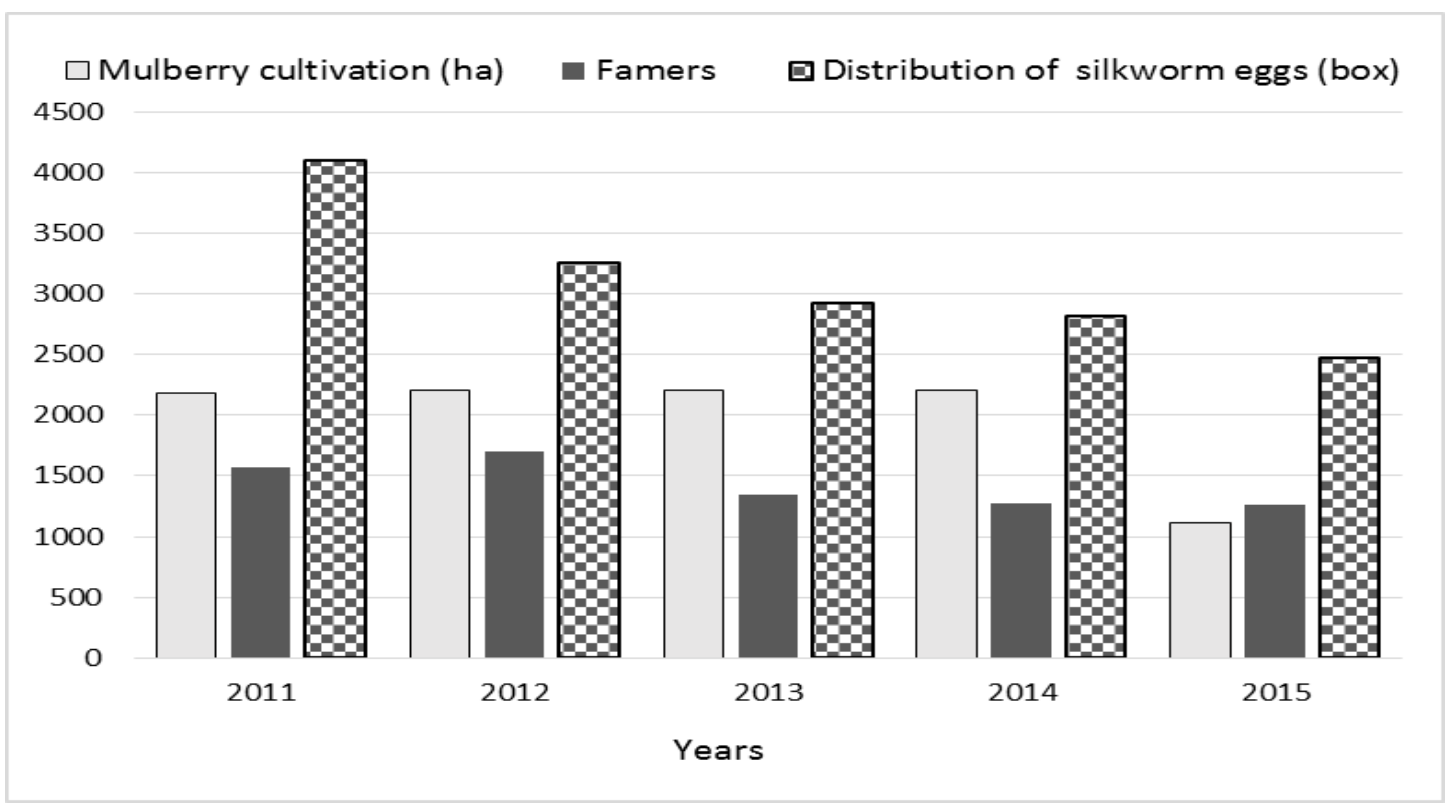

Figure 3. Mulberry cultivation, number of silk farmers and egg distribution in Sulawesi region (BPSKL, 2016)

\subsection{Problem Identification}

The focus of this study is on the three regencies that are the major centers of community silk and silkworm production. These locations help to identify the source of silk industry challenges at each segment, including the upstream and downstream aspects of the industry. The segments, 
geographies, levels, and organizational aspects are highlighted in Table 1. The development and success of natural silk industry is measured by its progress at aspects among each segment and other supporting instruments, which include fertilizer, eggs, stock, breeding, and the reasons behind low quality or failure of the cocoon, raw silk production, and their overall supporting organizations. The availability of fertilizer is evaluation by the size of the area and the management of the mulberry plants and the silkworm stock production. Silkworm productivity is contingent on the management practices related to maintenance procedures such as disinfectant treatments and other factors listed in Table 1.

Table 1. Problem Identification on each segment in three regencies and egg producer

\begin{tabular}{|c|c|c|c|c|c|}
\hline \multicolumn{2}{|l|}{ Segment } & \multirow{2}{*}{ Soppeng } & \multirow{2}{*}{ Wajo } & \multirow{2}{*}{ Enrekang } & \multirow{2}{*}{ Egg Producer } \\
\hline Upstream & Observation & & & & \\
\hline \multirow[t]{2}{*}{$\begin{array}{l}\text { Mulberry } \\
\text { field }\end{array}$} & $\begin{array}{l}\text { Condition of the } \\
\text { area }\end{array}$ & $\begin{array}{l}\text { Declining, } \\
\text { some of } \\
\text { them have } \\
\text { been } \\
\text { converted to } \\
\text { cacao }\end{array}$ & $\begin{array}{l}\text { Declining in } \\
\text { farmer level. } \\
\text { Supported by } \\
\text { KPH Awota, } \\
\text { which gave } \\
25 \text { ha. }\end{array}$ & $\begin{array}{l}\text { Declining, } \\
\text { mostly have } \\
\text { been } \\
\text { converted to } \\
\text { seasonal } \\
\text { plants. }\end{array}$ & Constant \\
\hline & $\begin{array}{l}\text { Maintenance/Fertil } \\
\text { izer }\end{array}$ & No & No & No & $\begin{array}{l}\text { Low } \\
\text { frequency }\end{array}$ \\
\hline \multirow[t]{7}{*}{$\begin{array}{l}\text { Silkworm } \\
\text { Rearing }\end{array}$} & Type of stock & $\begin{array}{l}\text { From local } \\
\text { producers }\end{array}$ & $\begin{array}{l}\text { From local } \\
\text { producers }\end{array}$ & $\begin{array}{l}\text { From local } \\
\text { producers }\end{array}$ & C103 \\
\hline & Cultivating pattern & $\begin{array}{l}\text { Independent, } \\
\text { rearing from } \\
\text { eggs until } \\
\text { harvesting }\end{array}$ & $\begin{array}{l}\text { Independent, } \\
\text { rearing from } \\
\text { eggs until } \\
\text { harvesting }\end{array}$ & $\begin{array}{l}\text { Independent, } \\
\text { rearing from } \\
\text { eggs until } \\
\text { harvesting }\end{array}$ & $\begin{array}{l}\text { Independent, } \\
\text { rearing from } \\
\text { eggs until } \\
\text { harvesting }\end{array}$ \\
\hline & Rearing Method & Shelf & Shelf & Shelf & $\begin{array}{l}\text { Shelf } \\
\text { and/without } \\
\text { rearing trays }\end{array}$ \\
\hline & Disinfection & Seldom & Seldom & $\begin{array}{l}\text { only some } \\
\text { farmers }\end{array}$ & $\begin{array}{l}\text { Egg } \\
\text { disinfection is } \\
\text { not done }\end{array}$ \\
\hline & $\begin{array}{l}\text { Production } \\
\text { challenges }\end{array}$ & $\begin{array}{l}\text { Pebrine and } \\
\text { grasserie } \\
\text { diseases }\end{array}$ & $\begin{array}{l}\text { Muscardine } \\
\text { disease and } \\
\text { grasserie }\end{array}$ & $\begin{array}{l}\text { Pebrine and } \\
\text { grasserie }\end{array}$ & $\begin{array}{l}\text { Pebrine and } \\
\text { grasserie }\end{array}$ \\
\hline & $\begin{array}{l}\text { Cocoon } \\
\text { productivity (per } \\
\text { box) }\end{array}$ & $\leq 10 \mathrm{~kg}$ & $\leq 20 \mathrm{~kg}$ & $\leq 10 \mathrm{~kg}$ & No data \\
\hline & $\begin{array}{l}\text { Post-cocoon } \\
\text { harvesting }\end{array}$ & $\begin{array}{l}\text { self-raw silk } \\
\text { reeling }\end{array}$ & $\begin{array}{l}\text { self- raw silk } \\
\text { reeling }\end{array}$ & $\begin{array}{l}\text { the cocoons } \\
\text { are sold }\end{array}$ & $\begin{array}{l}\text { the cocoon } \\
\text { becomes } \\
\text { seed }\end{array}$ \\
\hline \multicolumn{6}{|l|}{ Downstream } \\
\hline $\begin{array}{l}\text { Weaving } \\
\text { industry }\end{array}$ & Source of cocoon & $\begin{array}{l}\text { there is no } \\
\text { source }\end{array}$ & $\begin{array}{l}\text { there is no } \\
\text { source }\end{array}$ & $\begin{array}{l}\text { there is no } \\
\text { source }\end{array}$ & $\begin{array}{l}\text { there is no } \\
\text { source }\end{array}$ \\
\hline \multirow[t]{2}{*}{ gedogan } & Type of thread & $\begin{array}{l}\text { mostly } \\
\text { synthetic }\end{array}$ & $\begin{array}{l}\text { mostly } \\
\text { synthetic }\end{array}$ & $\begin{array}{l}\text { mostly } \\
\text { synthetic }\end{array}$ & - \\
\hline & Source of thread & import & import & import & - \\
\hline \multirow{2}{*}{$\begin{array}{l}\text { manual } \\
\text { weaving } \\
\text { industry }\end{array}$} & Type of thread & $\begin{array}{l}\text { mostly } \\
\text { synthetic }\end{array}$ & $\begin{array}{l}\text { mostly } \\
\text { synthetic }\end{array}$ & $\begin{array}{l}\text { mostly } \\
\text { synthetic }\end{array}$ & - \\
\hline & Source of thread & import & import & import & - \\
\hline Assistance & No & No & No & No & - \\
\hline $\begin{array}{l}\text { SSC } \\
\text { Organization }\end{array}$ & Not functioning & $\begin{array}{l}\text { Not } \\
\text { functioning }\end{array}$ & $\begin{array}{l}\text { Not } \\
\text { functioning }\end{array}$ & $\begin{array}{l}\text { Not } \\
\text { functioning }\end{array}$ & $\begin{array}{l}\text { Not } \\
\text { functioning }\end{array}$ \\
\hline
\end{tabular}


The natural silk business is a well-established business that has evolved over generations in the three regencies of Enrekang, Soppeng and Wajo. In Soppeng and Enrekang, the business developed more on the upstream segments (cultivation and production) while the downstream segments are predominantly located in Wajo. Soppeng and Enrekang are well known as the base of silkworm rearing. Most farmers rear silkworms to produce cocoons. Some of them weave the cocoons to produce thread. Meanwhile, Wajo regency is known because of its community weaving industry (tenun bola/gedogan), which produces silk sarongs (lipa sabbe) and other manual weaving products.

\section{Discussion}

\subsection{Soppeng Regency}

Soppeng regency is known as the first center of sericulture production in South Sulawesi. The latest figures of development in April 2017 in Soppeng indicate remaining mulberry field cultivation at 38.65 hectares, 72 households that remain active, producing 237.75 kilograms. This is far from the raw silk production figures in 1971, which were at 90 tons, mulberry cultivation at 5,500 hectares and 9006 households (Razak, 2017). During this period, in the height of natural silk production, amounted to 120 tons (Sukardi, 1995) and Soppeng regency contributed to over $75 \%$ of national production. Silk products drastically fell to 30 tons however in 1972/1973 due to a prolonged draught (Sukardi, 1995) and a pebrine outbreak (Gitosewojo, 1995; Disperindag Sulsel, 2006). Until the 1990s, the industry experience difficulty recovering because of competition from other commodities, especially the strong emphasis on cacao production, and the downturn of cocoon and raw silk prices. Organizations that were created like the SSC in 2008 have also not operated as expected. According to Razak (2017), the challenges for sericulture in Soppeng regency are the lack of availability of silkworm eggs of high quality, the lack of agriculture extension programs that support farmers to develop natural silk, and the lack of public interest to go into silk, lack of credit lines of silk, and the lack of infrastructure to protect against disease and maintain healthy worms, the lack of knowledge among farmers to fulfill the maintenance requirements as set out in technical guidance manuals.

\subsection{Wajo Regency}

The upstream segments, the farmers are always experiencing losses. Silkworm rearing only produces about 20 kilograms $(\mathrm{kg})$ per box since the quality of the seeds are deteriorating. Pebrine disease, as well as another culprit (Grasserie disease) has become a threat for achieving successful harvests. Rearing space conditions are not hygienic because the production areas are joined with other household activities. Tools for rearing larvae and cocooning are made from bamboo and wood, which tend to be worn out and old. The low quality of the cocoon and filaments is represented by the raw silk percentage of cocoon; 8-10 kg of cocoons are needed to produce one $\mathrm{kg}$ of raw silk yarn. At the time of writing there are no training organizations and Silk Solution Centre.

In the downstream segments, a lot of weaving industries have become idle due to the lack of cocoons. The craftsmen have difficulties obtaining local silk thread so that they are forced to pay for more costly imported thread to stay in business. Gedogan craftsmen have thus shifted mostly to using synthetic thread while manual weaving industries use synthetic thread and import silk thread even though the price is remarkably higher. Local silk thread costs only $500,000-600,000$ Indonesian Rupiah (IDR), or approximately 40 USD), meanwhile imported thread from China costs up to one million IDR, or 74 USD).

The Forest Management Unit (KPH) Awota began some activities regarding natural sericulture including organizational activities, partnership with farmer groups, and opening new fields for mulberry cultivation under agroforestry programs. The area is 25 ha with fence or path patterns. 


\subsection{Enrekang Regency}

The number of silk farmers in Enrekang is decreasing because some of them have converted to other commodities. In the early 2000s, farmers in Enrekang were spread across 6 subdistricts, occupying 16 villages (Sadapotto, 2004). As of 2017, farmers remain only in Alla subdistrict. The farmers here continue to rear silkworm with poor conditions. The tools which are made from bamboo have been worn out. In addition, there is no training and assistance for the farmers.

In the past ten years silkworm farmers in Enrekang have left the industry because they too often incur loses. Farmers generally maintain silkworms six times in a year. Each period of maintenance only yielded cocoons of 5 kilograms per box, and in some occasions completely lost the stock because of disease outbreaks. The disease that is most serious is grasseries and pebrine. This was confirmed in observations by BPA in 2011, in that from $78 \%$ of discovered larval losses, 41.2\% were attacked by Pebrine, 33.8\% from Grasserie, and 3\% from other bacterial causes (Majid, 2011). Failed production will not recover any costs and could also mean a loss of valuable time, labor, and fertilizer Disease outbreaks often take place when using local larval production from Perum Perhutani. Once imports were permitted, farmers began to prefer imported stock that would be more resistant to disease, albeit more expensive. Farmer losses at each failed harvest never received any assurances from the egg producers or by any local government guarantors. Stock producers and support programs from the Regency Forestry Agency claimed that the sources of disease were due to the reason that they were unwilling to follow standard operational maintenance guidelines. Indeed farmers tended to follow ad hoc management practices that were not always appropriate for avoiding disease.

Due to the losses and poor returns, farmers began to choose other horticultural products, intercropping mulberries with vegetables and keeping the mulberries cropped short. The first 2-3 years, the vegetables yielded better returns than silk. Common cultivation practices among vegetables in the region rely heavily on insecticides however. Insecticide use in multiple cropping systems with vegetables are a severe mistake for success in silkworms however. The ensuing challenge of caring for silkworms among mulberry leaves in contact with insecticides are also likely to kill silkworms and thus impact all phases of mainetenance.

\subsection{Egg Producer}

The only surviving silkworm eggs are supported by Perum Perhutani. One important finding from direct observations is in regards to egg provision. Before the eggs are subjected to $\mathrm{HCl}$ treatment, they are supposed to be disinfected with formalin solution at $2 \%$ for 15 minutes. However, this process is not conducted by the producers. Perum Perhutani, as the only producer of silkworm seed, always experiences losses in the billion rupiahs annually. Most expertise who have a deep understanding of natural sericulture production have retired and new recruitment has not prioritized knowledge development in this field. Available tools are also old and worn out, and do not support best practices and optimal production.

The Perum Perhutani only produces one variant of the F1 seed, which is vulnerable to disease outbreaks. This variant is a cross-breed of Japanese and Chinese lines which lay eggs only twice a year (bivoltine race). The F1 seed produced by Perum Perhutani is one of several technologies produced by ATA-72, an partnership agreement with the Japanese government. The technology also involves environmental sanitation. The sanitation process relates to the process whereby after the silkworms have finished the process of molting, they must be cleaned with a mixture of chalk and chlorine. The clearance of rearing shelf is done in each instar. It must be done more often (a minimum 3 times) in instar 3 until instar 5 . Bivoltine race is very suitable for development in subtropical area or areas where conditions are similar to subtropical areas. This makes Enrekang, located at 550-750 meters above sea level, with a daily temperature range from $23-27^{\circ} \mathrm{C}$ and average humidity $90 \%$, a suitable location. For example, in Kalosi village, Alla subdistrict, there is a silkworm farmer who consistently applies standard silkworm rearing practices. Disinfection is done at every rearing period. The result can reach $30-40 \mathrm{~kg}$ per box. 
In Soppeng and Wajo, the condition is different from the standard of bivoltine race rearing. These two regencies are located 400 meters above sea level with a temperature of $27-33^{\circ} \mathrm{C}$ and humidity at $55-70 \%$. Some other tropical countries conducting sericulture rear polyvoltine or multivoltine races, which are adaptive to those environments and more resistant to disease. In India, $91.44 \%$ of the seed are polyvoltine and only $8.56 \%$ is bivoltine (Askar, 2013). Thailand also experience failures in rearing bivoltine race. However, now Thailand develops three hybrid seeds from cross breeding of bivoltine and local polyvoltine (testimonial from Saikwan Trisunan, Chul Thai Silk Co., Ltd). In India available commercial stock available includes 16 hybrids (Askar and Mustamin, 2011) from a cross of multivoltine $x$ bivoltine (Gangopadhyay, 2008).

Looking to examples from Indonesia, low quality seed is also a problem in West Java. In addition to genetic factors, another important factor is the operational standard which is not properly applied by producers. The produced eggs are supposed to be subjected to a disinfection process with 2\% formalin for 15 minutes (Harizanis, 2007; Tripathi et al., 2011; Singh et al., 2012). This process is essential for preventing pebrine and grasserie.

\subsection{Silkworm Tools and Farmers Training}

Much of the silkworms rearing tools are damaged and have not been upgraded. The building sites critical for the rearing process is also damaged. These can be found in Enkerang. In Sabbangparu subdistrict, Wajo, the silkworm rearing is conducted under people's homes, whose floors are open soil and can become flooded during rains. These areas udner people's homes are also important for other household activities. Vehicle pollution also influences the quality and quantity of cocoons.

The rearing shelf is made of bamboo and layered with sarong, both of which lead to unhygienic that can compromise the rearing process. The tools have not been cleaned with chlorine, nor have they been exposed to sunlight for many years. The area is supposed to be painted with chalk and sprayed with formalin $2 \%$. The farmer also should wash their hands with formalin before feeding the worms. Overall, such unregulated and makeshift conditions highlight that there is a great need for guidance and training.

Law number $16 / 2006$ states that forestry training is to be conducted by civil servant trainers, private trainers and self-trainers, private sector extension officers, and other intermediaries. The Forestry Ministry rule number P.42/Menhut-II/2012 about Private Forestry Trainers and Community Forestry Trainers also states the requirement for training. Now, there are 4,760 community forestry trainers which could serve as potential trainers.

\subsection{Policy and the role of supervision}

The central role of the BPA is based on Forestry Ministerial decision No. 664/Kpts-II/2002 is to develop plans for natural silk production; maintenance of silkwork stock; production monitoring, circulation, and distribution; certification programing and organizational accreditation of silkworms; and, information management system for natural silk production (BPA, 2010). BPA evolved and became the Agency for Social Forestry and Environmental Partnerships (BPSKL) for the Sulawesi region based on Forestry Ministerial regulation No. P.14/Menlhk/Setjen/OTL.0/1/2016 that has a role of implementing activities for preparing social forestry programs regionally, developing a broad set of local enterprises, creating partnerships, as well as mapping out conflict in the field of social forestry (KLHK, 2015). Changes to the BPA meant that the proportion of the attention focused on silk production was no longer the case, because silk was now only a small amount of activities by the BPSKL Sulawesi region. The social forestry mandate for this agency is much broader, overseeing Community Forestry (HKM), Village Forests, Customary Forests, and other social forestry designations. The organizational role for the control and certification of stock and overseeing potential disease outbreak was now unclear. Although BPSKL had taken over this role, the resources availble in the institution and their large mandate meant that silk would become a much smaller priority. Therefore, these organization changes will indeed influence the overall prospects for sericulture going forward. 
Perum Perhutani is a state owned enterprise (BUMN) that has a mandate to manage protection and production forests amounting to 2.4 million hectares mostly in Java and Madura. Other than managing forests however, Perum Perhutani also engages in industrial programs, one of which is silk. Forestry Ministerial Decision letter No.122/KPTS-II/86 established in 1986 the Natural Silk Enterprise (PSA) in Soppeng. Perum Perhutani were given the authority to produce silkworm eggs with a capacity of 60,000 boxes but until this time only produce about 300-600 boxes per month. The latest survey of conditions highlight that PSA Perum Perhutani in Soppeng is limited and decreasing in staffing to operate the enterprise, four spinning machines that are in disrepair, and a spinning factory that requires maintenance, low silkyarn price that is not cahs and carry, and each year incurs average losses as large as 1.7 billion IDR per year, or $\sim 130,000$ (Perum Perhutani, 2017).

The SSC is an organization created from the implementation of the Joint Ministerial Rule of Ministry of Forestry No. P. 47/MENHUT-II/2006, in cooperation with the Ministry of Industry No. 29/M-IND/PER/6/2006 and the Ministry of Cooperation and Small and Medium Enterprises No. 07/PER/M.KUKM/VI/2006. The Joint Rule explicitly addresses coaching and development of national natural sericulture using a cluster approach and also explicitly mentions the master plan for natural sericulture. The Natural Sericulture Master plan states that in order to foster the development of national sericulture, a consultative organization is required. The SSC could perform the function of such a body. At the regency level, the SSC organization has already been established in Soppeng, Wajo dan Enrekang. However, the the supporting function have not been established or connected to the necessary facilitation at the central level. Therefore, there is a clear gap in the needs of supporting a thriving and growing national sericulture program that can provide the necessary functions of addressing the sericultural challenges described herein.

\section{Conclusion}

The low productivity of national sericulture caused by the pebrine epidemic, low quality of silkworm seed provision and handling, insufficiency rearing tools, and lack of guidance and assistance for the farmers. Overall, it is clear that national sericulture growth is failing for various reasons. This paper has highlighted the periods of pebrine epidemic to better analyze and understand the gaps behind these failures and better explain the challenges for creating a thriving natural sericulture industry. Surveys and interviews with three regencies in Wajo, Enrekang, and Soppeng indicate that both upstream and downstream production face steep challenges. First, the national government through the Agriculture and Forestry General Company (Unity of Natural Silk Entrepreneurs) must provide an improved bridging function for silkworm seed production. They also play a critical role to improve the standard of eggs handling, through practices such as applying disinfection to prevent disease. Second, there needs to be a more serious approach by the research institutions in the form of technical guidance and provision of production tools and best practices. Third, and finally, there is a clear gap in the availability and commitment to training. The SSC, and bridging the gap through partnerships between the central government and local governments can help to overcome some of the readily identifiable challenges to growing the industry. Finally, by addressing these key three critical areas, there is ample opportunity to supporting and re-invigorating a potentially thriving economy that can support rural livelihoods.

\section{Acknowledgments}

I would like to express my sincere gratitude to Mr. Masaki Tani (Head of the Japanese Consular Office in Makassar), Mr. Ichiro Ando (Ando Co.,Ltd) and Mrs. Saikwan Trisunan (Chul Thai Silk Co., Ltd) for their visit and concern for Indonesian sericulture. 


\section{References}

Askar. (2013). Kegiatan Persuteraan Alam India. Presented as Balai Persuteraan Alam (BPA) Kementerian Kehutanan Indonesia.

Askar \& Mustamin. (2013). Crop protection in India. Presented as Balai Persuteraan Alam (BPA) Kementerian Kehutanan Indonesia.

Aydin, L., Gullegen, E. Girigin O., \& Kurtaraner, L. (2007). Turkiye ipekboceklerinde Nosema bombycis (Naegeli, 1857) Olgusu. Turkiye Parazitoloji Dergisi, 31(1), 72-74.

Atmosoedarjo, S., Kartasubrata, J. Kaomini, M. Saleh, W. Moerdoko, W., Pramoedibyo \& Ranoeprawiro, S. (2000). Sutera Alam Indonesia. Yayasan Sarana Wana Jaya. Jakarta.

Balai PSKL Wilayah Sulawesi. (2016). Persuteraan Alam Wilayah Sulawesi. Kementerian Lingkungan Hidup dan Kehutanan. Jakarta

Bhat, S., Bashir, I., \& Kamili, A. (2009). Microsporidiosis of silkworm, Bombyx mori L. (LepidopteraBombycidae): A review. African Journal of Agricultural Research, 4(13), pp. 1519-1523.

[BPA] Balai Persuteraan Alam. (2010). Balai Persuteraan Alam Sulawesi Selatan. http://www.dephut.go.id/INFORMASI/PROPINSI/SULSEL/sulsel_1.html. Accessed on 2 September 2016.

[BPA] Balai Persuteraan Alam. (2013). Bahan Rapat Koordinasi Pengendalian Hama dan Penyakit. Makassar tanggal 15 Maret 2013.

[BPA] Balai Persuteraan Alam. (2015). Statistik Pengembangan Persuteraan Alam Tahun 2015. Kementerian Kehutanan. Direktorat Jenderal Bina Pengelolaan DAS dan Perhutanan Sosial.

[Disperindag] Dinas Perindustrian dan Perdagangan Provinsi Sulawesi Selatan. (2006). Program Pengembangan Industri Sutera Alam Sulawesi Selatan 2007-2010. Presented in Temu Bisnis Sutera Alam Sulawesi Selatan. Makassar. 12 p.

Etebari. K., Matindoost, L., Mirhoseini, S.Z., \& Turnbull, M.W. (2007). The effect of BmNPV infection on protein metabolism in silkworm (Bombyx mori) larva. ISJ. 4, 13-17.

Fahmid, I.M., Ridwan, Saleh, M., Basir, Z., Ahmad A., \& Afandi, A.I. (2011). Tantangan Komprehensif Persuteraan Alam di Sulawesi Selatan. Dinas Kehutanan Provinsi Sulawesi Selatan and Institute for Social and Political Economic Issues, Makassar

Gangopadhyay, D. (2008). Sericulture Industry in India - A Review. India, Science and Technology. http://www.nistads.res.in/indiasnt2008/t6rural/t6rur16.htm.

Gitosewojo (1995). Peluang pengembangan persuteraan alam di Indonesia khususnya di Jawa Barat. Presented in Seminar Nasional Persuteraan Alam. Bandung 30 Januari 1995.

Guo-Ping, K and Xi-Jie, G. (2011). Overview of silkworm pathology in China. African Journal of Biotechnology. 10(79), 18046-18056.

Govindan, R., Narayanaswamy, T., \& Devaiah, M. (1997). Pebrine disease of silkworm. Bengalore: University of Agricultural Science.

Harizanis, P.C. (2007). Manual of Sericulture Silkworm Rearing Mulberry Cultivation. Agricultural University of Athens Laboratory of Sericulture \& Apiculture.

Hussain, A., \& Buhroo, A.A. (2011). An alternative method to secure pebrine free silkworm eggs. International Society for Zoological Research (ISZR). International Journal of Entomology. 2(1), 40-42.

[JICA] Japan Interntional Cooperation Agency. (1985). Proyek Pengembangan Persuteraan Alam di Indonesia. Buku Pelengkap Audio Visual. 77 p.

[KLHK] Kementerian Lingkungan Hidup dan Kehutanan. (2015). Lampiran Peraturan Menteri Lingkungan Hidup dan Kehutanan Republik Indonesia Nomor: P. 39/Menlhk-Setjen/2015 Tentang Rencana Strategis Kementerian Lingkungan Hidup dan Kehutanan Tahun 2015-2019.

Nath, B. S., Gupta, S. K., \& Bajpai, A. K. (2012). Molecular characterization and phylogenetic relationships among microsporidian isolates infecting silkworm, Bombyx mori using small subunit rRNA (SSU-rRNA) gene sequence analysis. Acta Parasitologica. 57(4): 342-353. 
Government of Indonesia (2007). Peraturan Pemerintah Republik Indonesia Nomor: 6 Tahun 2007 Tentang Tata Hutan dan Penyusunan Rencana Pengelolaan Hutan, Serta Pemanfaatan Hutan.

Perum Perhutani. (2017). Membangun Kembali Potensi Sutera Alam Sulsel Melalui PSA Soppeng. Disampaikan pada rapat koodinasi Persuteraan Alam Wilayah II pada Tanggal 10 Mei 2017 di Makassar.

Potrich M., Alves, L.F.A., Brancalhão, R.C., \& Dalcin, G. (2007). Entomopatógenos associados a lagartas de Bombyx mori L. (Lepidoptera: Bombycidae) no estado do Paraná. São Paulo: Arq. Inst. Biol. 74(4), 363-367.

Razak, K. (2017). Strategi Pengembangan Persuteraan Alam di Kabupaten Soppeng. Presented in the Coordination Meeting Persuteraan Alam Wilayah II in 10 May 2017, Makassar.

Sadapotto, A. (2004). Kerjasama dalam pengembangan sutera di Sulawesi Selatan. Institut Pertanian Bogor. http://www.rudyct.com/PPS702-ipb/09145/andi_sadapotto.pdf. Accessed on 24 May 2017.

Singh, T., Bhat, M. M., \& Khan, M. A.. (2012). Microsporidiosis in the Silkworm, Bombyx mori L. (Lepidoptera: Bombycidae). Tropical Agricultural Science. 35 (3), 387 - 406.

Sukardi, P. (1995). Pengalaman Pengembangan Usaha Sutera Alam di Sulawesi Selatan. Presented in Seminar Nasional Persuteraan Alam. Bandung 30 Januari 1995.

Tripathi, SK., Shukla, S.K., \& V.B. Upadhyay. (2011). Shell ratio changes under magnetic exposure of eggs in Bombyx mori: A multivoltine mulberry silkworm. Academic Journal of Entomology 4(2): 47-50.

Watanabe, H. (2002). Genetic resistance of the silkworm, Bombyx mori to viral diseases. Current science. 83(4), 439-446.

Yup-lian, L. (1991). Silkworm Disease. Rome: FAO Agricultural Services Bulletin 73(4). 75 p. 